\title{
Episodic Literary Movement and Translation: Ideology Embodied in Prefaces
}

\section{ABSTRACT}

This paper discusses translation practices from a historicist viewpoint, contextualizing them in their emerging "episode." The latter is a concept drawn from sociology of literature and accounts for the rise of certain discourses and ideologies in a society. On the basis of the argument that translation practices are informed by the general literary and sociocultural milieu in which they are produced and consumed (also known as ideology of representation), the paper studies the translators' prefaces to three translations published between 1953 and 1978-a period dominated by Leftist and Marxist discourse in Iran. Drawing on a historically oriented model which holds that the translator's ideology is revealed at the moment in which he/she chooses a text, and continues through the discourse he/she develops to translate that text, the research embarks on studying translation practices on two levels of choice mechanism and prefaces. Prefaces are discussed in the light of the dominant ideology of representation that is characterized by a revolutionary discourse. The research demonstrates that these translators opted for a strategy that incorporates the translations in the Persian cultural setting with minor changes in a way that politicizes the foreign literature.

Keywords: episode, ideology of representation, translation practices, prefaces, Marxism. 


\section{INTRODUCTION}

Understanding cultural products, including literature, in the context of their creation is the main tenet of historicism (Malpas 55). The concept of "episode," first developed in sociology, is a concept deeply rooted in the historicist approach for it has some connections with the historical context of cultural production. Episode refers to "a cluster of interrelated, aesthetically significant literary texts that form a discursive movement in a particular historical period," each cluster demonstrating "a harmony within itself and a difference with others" (Talattof 8). Since we are dealing with such texts here, literary translation can be included in this episodic approach, as well. Given that excluding the role history and ideology play in the process, as well as in the final product of translation leads to a curtailed account of translation practices, such an episodic approach is not foreign to Translation Studies.

This study draws on Talattof's concept of episodic movement to investigate the translation practices of a certain episode in modern Persian literary history, an episode which he calls "Revolutionary Literature" or "Committed Literature" (Talattof 2). The episode begins with the USled coup in 1953 and ends with the 1979 Revolution. First, an account of the features of this episode will be given and then some translation practices will be analyzed in light of the episodic movement. The practices are materialized in prefaces to translations published in the period. The translations - the prefaces to which I study here-are selected because they were widely read in Iran in the period under study. Moreover, their translators are among the best-known in the intellectual circles of the time and the publishers were among the most celebrated. There were many other works translated from the Anglo-American tradition which were either unpopular or without any significant paratextual material that would meet our criteria. (For more information on the literary history of the period see below, as well as Talattof.) The books selected are translations of the following works:

Paton, Alan. Cry, the Beloved Country. Translated by Fereydun Saleki and Nader Ebrahimi. Amir-Kabir, 1969. [The Persian title: Muye kon sarzamin-e Mabbub]

Paton, Alan. Cry, the Beloved Country. Translated by Simin Daneshvar. Kharazmi, 1972. [The Persian title: Benal vatan]

Hawthorne, Nathaniel. The Scarlet Letter. Translated by Simin Daneshvar. Kharazmi, 1967. [The Persian title: Dagh-e nang]

Eliot, Thomas Stearns. The Waste Land. Translated by Parviz Lashkari. Nil, 1972. [The Persian title: Dasht-e satarvan] 


\section{THE EPISODIC LITERARY MOVEMENT AND TRANSLATION PRACTICES}

"Ideology of representation" refers to the dominance of a particular ideology in literary representation which engages much of the literary creativity of an era (Talattof 10). Thus, episodic literary movements are caused by factors such as socio-political changes and guide the mode of reading - and, by extension, translating - in a period, making a discourse prevail (15-16). Metaphor, defined here as something beyond a mere linguistic device, is to perceive a sign in terms of other signs, and since it conveys ideology, it is important for episodic literary movement (12). Each literary movement has a specific way of conveying meaning through "theme (the substance, the idea), characterization (the dialogue, the strategy of behavior), form (the shape, the structure), and style (the mode of expression, the figurative language)" (8). Readers interpret the texts, metaphors and ideology implicit in them in accordance with the dominant discourse. Talattof calls this "discursive interpretation" (16-18). Such an episodic fashion can happen in other areas of discursive practices specifically in translation because with the change in social formations new translation practices rise (Venuti, "Translation, History, Narrative" 804).

The translator's "positionality" (von Flotow 13) or "historicity" (Gouanvic 94) is manifested in the choice that he or she makes in the very first stage. The choice is definitely ideological: the choice of texts and the discourse developed to translate them, Venuti asserts, are charged with ideological issues and are strategic in nature (Scandals 10).

Since this study focuses on the role of the episodic literary movement in translators' prefaces, analyzing prefaces constitutes an important part in our analysis. In historical investigation, they sometimes provide information on translation practices that the text itself falls short of (TahirGurçağlar 59). As Simon states, prefaces are indicative of the "prominence given to the translator" (111) and the most important statements about translation are made in the prefaces, "that is in a context where the focus on immediate readership is foremost" (ibid.). She believes that prefaces are both action and speech and that they bring their authors protection from the "outrages of power" (ibid.). In spite of the fact that we cannot take translators at their word regarding what they write in their prefaces and what they actually practice, we can link the agenda behind prefaces to their respective political context: "In addition to revealing the historically shifting relationship between author and translator and foregrounding the foundations of literary values, prefaces are useful precisely because they trace the contours of literary ideology and expose for us the sociopolitical 
context which commands literary exchanges" (Simon 112). As a result, translators' prefaces can be regarded as being on the same level as the translation itself when exploring the relationship between episode and translation practices.

\section{THE EPISODE OF "REVOLUTIONARY LITERATURE"}

" $[\mathrm{R}]$ evolutionary literature within a revolutionary social context," or "politics of poetics," as Hamid Dabashi puts it, is the dominant literary practice in the episode of "revolutionary literature," where the term "revolutionary" embraces both social and political senses (147). Commitment is defined as "a presuppositional engagement with and concern for social causes, revolutionary ends, and ideological statements" (149). Committed literature in the context of prerevolutionary Iran, which was translated as adabiyyat-e mota'abhed, is seen in the work of writers like Samad Behrangi, Jalal Al-e-Ahmad and many others (see Dabashi). Whatever the authors' background are-aristocratic, middle- or upperclass - they have one thing in common: the "mystical glorification of the masses" (Dabashi 154). That is to say, the masses are regarded in the work of these writers as the principle social group which should be freed from "the bonds of poverty, ignorance, and tyranny" (155) because a revolution would not be possible without the workers' gaining knowledge about their situation.

Dabashi's categorization of different modes of poetics vis-à-vis politics is more intricate and accurate, and transcends the aestheticpolitical dichotomy. He sees three sets of literary practice (171-72): 1) literature devoted to revolutionary and ideological ends where poetry acts like a "rifle"; 2) literature that is "atomized and isolated from society"; and 3) literature that stands somewhere between the two above, where aesthetic and political issues are appreciated at the same time. The third type is the most important one in terms of its political content: "[i]n this literature social problems and political repressions are clearly expressed, but they are not its raison d'etre" (177). Writers like Gholamhossein Saedi and Al-e-Ahmad belong to this group. In a bid to contribute to the sociopolitical causes which committed writers encouraged the masses to form, they dispelled the traditional inhibition and normativeness imposed upon classical literature (180).

The Left's analysis of "the woman question" was a class-based one where women from different classes were exploited in various ways. Besides, the dominant imperialist culture, "male chauvinism" with its "concomitant religious mentality," also had a role in exploiting women in 
a cultural way (Shahidian 227-28). Cultural imperialism was considered to be the main culprit in the corruption of youth. According to this view, "[w] omen's oppression was attributed now to world imperialism and its internal allies - the Shah's state apparatus and the comprador bourgeoisie-rather than to the social, economic, political, and cultural conditions of Iranian society itself" (230).

One of the main concerns of the intellectuals, particularly in the 1960 s and 1970s, was the "authentic culture" or Eastern (domestic) culture as opposed to the Western one (Nabavi 92). The reasons behind the proliferation of the authentic culture among the Left-leaning intellectuals are twofold: 1) given the constraints that the Pahlavi regime had placed on political activism, the intellectuals found "less direct avenues to express their opposition" that led in time to an increase in the number of intellectual publications; and 2) the success of "Third Worldist movements" in resisting imperialism (Nabavi 92-93). Iranian intellectuals used "third world issues allegorically to refer to the state of affairs in Iran" (93). By attacking imperialism, which they could criticize, the intellectuals leveled criticism at the status quo, revealing the powers that supported the Shah's regime which, they believed, was a product of Western imperialism (ibid.).

In order for the intellectuals to be able to raise "national consciousness" and to awaken people, they had to revert to the past, which helped create the authentic culture discourse. Although some intellectuals distinguished between the imperialist and the Western culture that should not be rejected in its entirety, the general trend was to recover the authentic, "Eastern" culture and to question the Western cultural influence (94).

The state also got involved with this Left-leaning discoursethough it adopted the discourse of the 1960s Left-and implemented a number of cultural policies similar to those of the anti-establishment or Third-Worldist intellectuals. Yet there is a difference between these two: "Whereas disenchanted intellectuals, by and large, included a degree of anti-Westernism as a manifestation of their third-worldism, for the establishment, promoting authentic culture did not necessarily equate with opposition to the West" (97). The establishment, therefore, used the third-world discourse to unite the nation and to make it understand its cultural heritage. This discourse, however, was significantly different from the one adopted by the anti-establishment intellectuals in that the establishment tried to reconcile with the West rather than confront it. For the intellectuals, it was not putting on display the cultural tradition through festivals, for example, that could "stimulate social consciousness" but reintegrating the past into the life of people that could do better to achieve such a goal (100). 
Ali Shariati, a key thinker at the time, proposes concepts like "return to oneself" (bazgasht be khishtan). His approach to Islam is different from the conventional approaches current in the decades leading to the Islamic Revolution. Shi'ism, considered by Shariati to be revolutionary, is mixed with a variety of Western philosophies like existentialism and Marxism. Regarding the issue of culture and society, Shariati sees the class differences of the Sassanid era, the resulting feudalism in the Islamic era and frequent foreign offenses against Iran as the main culprits leading to the lack of national harmony (Gheisari 99). Also, Western ideologies have affected Iranian identity in various ways; modernism, for example, makes an "Iranian or Muslim modernist ... feel as if he had closer ties to Western culture than to his own" (100). He believes that the Western intellectuals emerged in the European context in reaction to Christianity, and that the Iranian intellectuals must not blindly follow the same line. He proposes an alternative definition of the intellectual in terms of response to an Islamic culture (ibid.). What Shariati attempted to propagate was a mixture of trends that had purely Western roots, notably Marxism, and the authenticity discourse. He sees a sort of atheism in Marx, which is in opposition to Islam. When revolutionary Marxism is mixed with Islam, they can both form a revolution and radical change in society (Mirsepassi 122).

\section{TRANSLATION PREFACES IN LIGHT OF THE METAPHOR AND DISCURSIVE INTERPRETATION}

Metaphor is a key concept in Talattof's framework as it makes possible the expression of ideas which would have been censored by the Pahlavi establishment if they had been put into explicit terms. For instance, "night" in the work of the committed writers is a metaphor of the Shah's regime, not the night in its conventional sense. Under socio-political circumstances which prevent writers from engaging directly with the sensitive political matters on the ground, making them resort to metaphors, translation is also a metaphoric activity that can escape the eyes of the censors. Translators choose texts that have a potential to be read and translated on the basis of dominant discourse and apply a discursive interpretation to the foreign text which can convey the ideology they have in mind.

\section{CRY, THE BELOVED COUNTRY}

In the preface to their translation of Cry, the Beloved Country, Saleki and Ebrahimi begin with an ironic point about the situation of the whites and blacks in South Africa: 
South Africa... is seemingly located in the south of the African Continent [sic] and has a population of about fifteen million. Out of this fifteen million, nearly two million are white and they have obviously the fate and lives of the remaining thirteen million in their hands; that is to say, the rule of white elites on the black masses. ${ }^{1}$ (Saleki and Ebrahimi 5)

After pointing out how the first white settlement was set up (in 1652) in South Africa by the "well-known and equality-seeking 'East India Company" (ibid.), the translators recount how Great Britain dominated the "lowly" South Africa in 1841. Great Britain, they believe, found their precursors' method incorrect and drove these "occupiers" of South Africa to the North in order to "return to the blacks their rights [sic]" (ibid.). Apartheid, a discriminatory law against black people, was passed after the Second World War. According to this law, which the translators sarcastically call "a bright, humanitarian and prideful project," blacks were sent to mines to work and were threatened with punishment if they avoided working. "The tactfulness of a threat," the translators state ironically, "lies in the way it is carried out, and the Europeans are tactful enough" (6). This sarcastic tone is evident in the remaining part of the preface, where Verwoerd is quoted as uttering imperialistic sentiments about black people, calling for their presence in South Africa as "cheap work-force" (ibid.). They even call into question the role of international bodies like the United Nations and quote a Persian encyclopedia's entry that states that the General Assembly of the United Nations only "lamented" the racial policy in the country in 1959 (ibid.). This "brave lamentation" fell flat when in the following year a large number of black people were punished "brotherly" (7). For translators, the supporters of racism in South Africa are "American racists, racist organizations in Britain, all of the European fascists, the majority of the religious missionaries, and all of the colonizers of Africa and of other continents in the world" (ibid.).

Simin Daneshvar has published a Persian translation of Cry, the Beloved Country as Benal vatan. The preface to her translation is replete with direct and indirect references to colonialism and imperialism in the main setting of the novel-Africa-but with metaphorical points that contextualize the translation in contemporary Persian culture and politics. She likens the South African situation to a "chess game" in which the African natives are supposed to be the black pieces and the colonizers the white. She is very optimistic about the future of South Africa where she states the black population would learn how to play the game someday. Yet, the colonial game in South Africa is more evident than in any other country stricken by

1 All the translations of the extracts from prefaces are by the author. 
colonial domination. In other countries, this game goes on clandestinely (Daneshvar, Preface to Cry 7). This translator also brings out the issue of apartheid whereby black people are deprived of the natural right to determine their own destiny. The supporters of the central government, that is, "owners of industry and of gold and diamond mines," found the status quo appropriate for their benefits. Apartheid, as the main point of this preface, paves the way for further exploitation of the native black population.

Daneshvar's translation of Cry, the Beloved Country is dedicated to the translator's husband, Jalal Al-e-Ahmad, who died in 1969, two years before the translation was published. Daneshvar writes:

Once more for your memory and your name, Jalal Al-e-Ahmad, Whose characteristic was his name [Jalal],

Pity for all that fortitude.

Simin

The praise extended to Al-e-Ahmad whose first name is Jalal (meaning "glory" in Persian) is of great importance because the book is dedicated to one of the most prominent committed writers of the period, Jalal Ale-Ahmad, with an influential oeuvre on the issues pertinent to activism, Westoxication, colonialism, imperialism and the authentic culture. The translator conceals behind her seemingly innocent dedication a sort of political activism that is reflected in her choice of work. The black-white dichotomy, justice and equality are the main threads that run through these prefaces. Daneshvar mentions in an interview that she was not content with her translations and the motive behind her translation activities was merely financial (Milani 10). She states that she translated Divine Comedy by Saroyan, for example, to buy a refrigerator; she therefore regards herself as a "victim" of translation because she had to translate due to financial problems (ibid.). Although she claims to be ideology-free due to her avoidance of joining any political party, she could not help being under the influence of the dominant ideology (13).

\section{THE SCARLET LETTER}

Simin Daneshvar has written a very illuminating preface to her translation of The Scarlet Letter by Nathaniel Hawthorne. The novel is about a woman subjected to unjust treatments in an extremely religious community. The translator found this theme similar to the concepts dominant at the time in Iran, namely, the Leftist demand of equality and justice for all people, including women. 
The translator's "Harfe Akber" ("The last word") is indicative of Westoxication discourse: the translator asserts that mere translating is dangerous in countries like Iran where there should be more creativity on the part of the domestic writers. She laments the fact that she translates instead of writing in Persian. She recounts two reasons for the dominance of translation over original composition in Iran from the $1950 \mathrm{~s}$ onward: 1) translation is much easier than original writing; 2) economically, since Constitutional Revolution translation has enjoyed a better market. She comments further on the second reason: translation is emphasized because, she argues, the people believe in others, particularly "the West," and less in their own compatriots (Daneshvar, Preface to Scarlet 5).

She resorts to the Westoxication discourse using terms like az khod biganegi (self-alienation) and gharbzadeb (Westoxicated). For her,

most of the contemporary translators know at least one foreign language well because they are trained in the West or Western and Westoxicated [gharbzadeb] schools, Persian being their mother tongue. It was thus that translation movements developed in Iran and many of our citizens bought translations and ... became self-alienated and ignorant of their rich treasury of literature and mysticism. (Daneshvar, Preface to Scarlet 6)

The translator believes that translation is a second-hand writing and that what would save Iran from being trapped in self-alienation is original compositions. Westoxication is again condemned here for alienating Iranian people from their rich literary history by forcing them, in one way or another, to translate Western literature.

The translator asserts her purpose in line with Hawthorne. The author, she believes, undertook writing such a book to improve the condition of women in his society because he seeks a world emptied of all these prejudices and turbulences. Introducing the author of the book and his other works she presents a picture of the place in which the story is set, New England. The last paragraph of Daneshvar's introduction summarizes what she thinks about the women's cause in the Iran of the 1960s:

An interesting point that occurs to the present writer is a hope that the author of the book [Hawthorne] holds for the betterment of women's condition and for a better world in which there is no sign of these vicissitudes and prejudices. Hawthorne hopes for a new woman who will become the future prophet of this world; a learned and meritorious woman who is the beacon of happiness and elation and the oracle of goodness and luck. This is a woman who can construct the man-woman relation on a better and wiser basis and disrupt the custom that others, 
that is, the mighty [zurmandan] of society, have wrongly imposed on women. The translator also undertakes translating this text in the hope of the coming of this woman. (Daneshvar, Preface to Scarlet 14)

One may see tinges of feminist discourse in this extract. The translator, an author well-known for having written Savushun, ${ }^{2}$ looks for a "learned and meritorious woman." She believes that there will be a day when all these prejudices against women will be eliminated. In one respect, she deviates from the Leftist approach to culture as such. The Left did not give any supremacy to the women's cause and placed it under the banner of national struggle. That is to say, what was important for the Left in Iran was not the women's cause but women's oppression under the yoke of imperialism and despotic regimes (see Shahidian).

\section{THE WASTE LAND}

Similar to these anti-imperialist and East-West discourses, yet to some extent directly applicable to Iran's contemporaneous discourse, is the one promoted by the likes of Jalal Al-e-Ahmad and Ahmad Fardid. The former is responsible for the widespread usage of the term both before and after the revolution. Parviz Lashkari's preface to his translation of T. S. Eliot's The Waste Land, published with Eliot's shorter poems, is replete with direct and indirect references to this concept. Lashkari begins his preface with the point that The Waste Land is the "hero-less epic of an era devoid of value" in which material embellishments have made us forget the meaning of "tradition" (Lashkari 5). Human beings have created an "invisible prison" where God and nature have lost their meanings and are replaced by the goddesses of the new era, viz. money, material power and the machine (ibid.). The author of the preface criticizes the machineworship which ruins the human being and makes him a dependent slave to the machine. The result of machine-worshipping is a man who does not have any purpose or social ideal (Lashkari 6). The translator calls The Waste Land an epic because "it recovers from among the dried bones of the dead the meaning of the ancient traditions and customs" in a world now devoid of prophets (6).

The text hinges around the East, pointing to the Westoxication discourse promoted by Al-e-Ahmad whose concept of return to the "roots" is a key term that pertains to resistance to "mechanosis" or mashin zadegi:

2 Savushun, the first Persian novel written by a woman writer. For more information on the novel, see Jafari. 
Al-e Ahmad argues that a "return" to an "authentic" Islamic culture is necessary if Iran is to avoid the homogenizing and alienating forces of socio-technological modernization. Yet, the "return" advocated by Al-e Ahmad was a rather complicated political discourse. Ahmad's populist Islam would not reject modernization as such, but would seek to reimagine modernity in accordance with Iranian-Islamic tradition, symbolism, and identities. (Mirsepassi 96)

This "authentic" Islamic culture, a return to which is necessary for embracing modernity, avoids Western frameworks. Al-e-Ahmad's romanticism denigrates reason in politics and promotes his Shi'i romanticism. This "reactionary modernism" is an "embodiment of the self-realization of a modern intellectual lost in the plight of modern life" (Mirsepassi 105). The "blind mechanization" that has dominated the Soviet Union and the US has annihilated all ideals. In keeping with Al-e-Ahmad's thinking, Lashkari refers to the present and the past of the East:

This is the beginning of an East that founded the spiritual civilization and this is the end of an East that asks for help from the shrine of "The New Age" that satisfies the needs of the Westerners in distant lands. Westerners have taken down the Heaven and set up an earthly Heaven and begun to worship it but have derived from it nothing but gluttony and laziness. (Lashkari 6)

The West, exhausted by this monotony, has turned to the East to find "God" who is also forgotten in the East's present. This bemusement is due to the fact that the West does not want either to abandon its "earthly Heaven" or its religiosity (7).

In a more direct reference to Westoxication as conceptualized by Al-e-Ahmad, the preface goes on to state that the West has cheated the East by providing it with "cosmetics" to embellish this "bride that has forgotten her mother"; this is done in order to make a familiar setting for the Westerner who comes to see this "Eastern bride" (7-8). Eliot's search for spirituality in a place other than the West leads him, as the translator states, to look to "Buddhism and Zoroastrianism" as alternatives to God that the West has lost. This East is partly represented for Eliot through Khayyam's poetry (1048-1131 CE) and through people who are not slave to their material needs and, though not fully fed, remain pious (8). In a more telling passage of the preface, the issue of mechanization is brought up again. The development and growth of the machine, Lashkari believes, have brought us an "invaluable souvenir" from the West, shed doubt on human beings' individuality and started a road whose end is not clear. The machine begins to annihilate the values inherited from the past 
and then sets the yoke of mechanization on people (9). This, in turn, leads to similarity and conformity among the people. Precisely at this time they begin to realize that they are no longer "backward" and that they have joined the ranks of the "developed" (10). The passage resonates with Al-eAhmad's idea about "nihilism" in the West brought about by the machine which, as he supposes, "must not be . . an autonomous mover beyond human ideals, ideology and tradition" (Mirsepassi 109). This nihilism is transferred to Iran through colonialism and imperialism.

The views of intellectuals on a domestic, authentic and Eastern culture as a prerequisite to modernity is clearly stated in this representative preface. Lashkari reverts to the past to provoke a domestically initiated thinking about modernity. The translator claims (maybe wrongly) that he shares with Eliot a notion of the East's glorious past. Foreign imperialism, as one of the key obstacles to the freedom of the masses, is obviously stated by the translator. The approach which the enemy, the West, adopts in the face of the Persian and Eastern culture is a sort of "cultural invasion" or tabajom-e farhangi. This latter term appears frequently in Al-e-Ahmad's writings and refers to a type of "cultural imperialism." According to the Left's approach to the issue of cultural imperialism, it was the Shah who paved the way for foreign imperialism. By choosing to comment on foreign imperialism in a preface, the translator-cum-activist wants to level clandestine criticism at the Pahlavi's political apparatus. We should also note the fact that not all things Lashkari writes in his preface to The Waste Land hark back to Eliot's works. They are rather the translator's own (mis)interpretation of the ideas contained therein.

\section{CONCLUSION}

Since prefaces guide the reading of a text and contribute to its discursive interpretation, they have been chosen to investigate the effect of ideology, episodic movement and discursive interpretation on translation practices. Unlike the readings or interpretations of general readers, translators are readers whose readings are made flesh. Their choice of work which is informed by the dominant discourse and ideology is indicative of their positionality. The practices that the translators undertake are a response and complement to the general episodic movement in which they are positioned. Translations have been traditionally considered less constrained by the state censorship because they are considered to be talking about other countries. Translators, however, have the power to criticize the status quo more covertly and contribute to the current discourses. 
Given the commentaries presented by the translators in their prefaces, it seems that committed translators tended to politicize literature (which is a discursive interpretation in light of the episode) rather than write political literature. The translators' subscription to the dominant "ideology of representation" is different from that of the anti-establishment and the socalled original committed writers in that the former do not use the text as a "rifle" against the regime. The sharpness of their language is, therefore, so blunted that they can escape censorship. In general, what is evident in the final analysis is the fact that the committed translators who had a political inclination particularly to the Left and its emancipatory promises were aware of the pressure that the Pahlavi regime had put on the anti-establishment camp; to avoid this they preferred to translate rather than write original texts. As a consequence, their allegorical references to Iran and the recourse to Leftist themes are the most important points about their translation practices.

\section{Works CiTED}

Dabashi, Hamid. "The Poetics of Politics: Commitment in Modern Persian Literature.” Iranian Studies, vol. 18, no. 2, 1985, pp. 147-88. https:// doi.org/10.1080/00210868508701656

Daneshvar, Simin. Preface [in Persian]. Cry, the Beloved Country, by Alan Paton, translated by Simin Daneshvar, Kharazmi, 1972, pp. 7-13.

Daneshvar, Simin. Preface [in Persian]. The Scarlet Letter, by Nathaniel Hawthorne, translated by Simin Daneshvar, Kharazmi, 1967, pp. 1-14.

Gheisari, Ali. Iranian Intellectuals in the $20^{\text {th }}$ Century. U of Texas P, 1998.

Gouanvic, Jean-Marc. "A Model of Structuralist Constructivism in Translation Studies." Crosscultural Transgressions: Research Methodology in Translation Studies II, edited by Theo Hermans, St. Jerome, 2002, pp. 93-102.

Jafari, Masoud. “Suvashun.” Encyclopedia Iranica, 12 Apr. 2012, https:// www.iranicaonline.org/articles/suvashun, accessed 2 Mar. 2021.

Lashkari, Parviz. Preface [in Persian]. The Waste Land, by Thomas Stearns Eliot, translated by Parviz Lashkari, Nil, 1972, pp. 1-9.

Malpas, Simon. "Historicism." Routledge Companion to Critical Theory, edited by Simon Malpas and Paul Wake, Routledge, 2004, pp. 55-65. https://doi.org/10.4324/9780203412688_chapter_5

Milani, Farzaneh. "Nilufare abi dar mordab ham miruyad [in Persian]." Nimey-e Digar, vol. 5, no. 4, 1987, pp. 5-24.

Mirsepassi, Ali. Intellectual Discourse and the Politics of Modernization: Negotiating Modernity in Iran. Cambridge UP, 2000. https://doi. org/10.1017/CBO9780511489242 
Nabavi, Negin. "The Discourse of 'Authentic Culture' in Iran in the 1960s and 1970s." Intellectual Trends in Twentieth-Century Iran: A Critical Survey, edited by Negin Nabavi, UP of Florida, 2000, pp. 91-108.

Saleki, Fereydun, and Nader Ebrahimi. Preface [in Persian]. Cry, the Beloved Country, by Alan Paton, translated by Fereydun Saleki and Nader Ebrahimi, Amir-Kabir, 1969, pp. 1-6.

Shahidian, Hammed. "The Iranian Left and the 'Woman Question' in the Revolution of 1978-79." International Journal of Middle East Studies, vol. 26, no. 2, 1994, pp. 223-47. https://doi.org/10.1017/ S0020743800060220

Simon, Sherry. "Translating the Will to Knowledge: Prefaces and Canadian Literary Politics." Translation, History, Culture, edited by Susan Bassnett and André Lefevere, Pinter, 1990, pp. 110-16.

Tahir-Gurçağlar, Şehnaz. "What Texts Don't Tell: The Uses of Paratexts in Translation Research." Crosscultural Transgressions: Research Methodology in Translation Studies II, edited by Theo Hermans, St. Jerome, 2002, pp. 44-60.

Talattof, Kamran. The Politics of Writing in Iran: A History of Modern Persian Literature. Syracuse UP, 2000.

Venuti, Lawrence. The Scandals of Translation: Towards an Ethics of Difference. Routledge, 1998.

Venuti, Lawrence. "Translation, History, Narrative." Meta, vol. 50, no. 3, 2005, pp. 800-16. https://doi.org/10.7202/011597ar

Von Flotow, Luise. "Women, Bibles, Ideologies." TTR: Traduction, Terminologie, Redaction, vol. 13, no. 1, 2000, pp. 9-20. https://doi. org/10.7202/037390ar

Mir Mohammad Khademnabi is Assistant

Professor at the Department of English Language of the University of Maragheh, Iran. He holds a $\mathrm{PhD}$ in Translation Studies from Ferdowsi University of Mashhad, Iran. His research activity has focused on translation history in Iran and reception studies.

https://orcid.org/0000-0001-7538-5855 mi.khademnabi@gmail..com 